Published by Al-Nahrain College of Medicine P-ISSN 1681-6579

E-ISSN 2224-4719

Email: iraqijms@colmed-alnahrain.edu.iq http://www.colmed-alnahrain.edu.iq

http://www.iraqijms.net

\title{
Molecular Characterization of the Oncogenic Potential and Mechanisms of Cytomegalovirus Infecting MRC-5 Cells
}

\author{
Ahmed S. Abdulamir PhD \\ Dept. of Microbiology, College of Medicine, Alnahrain University, Baghdad-Iraq
}

\begin{abstract}
Objectives

Methods
\end{abstract}

Background Human cytomegalovirus (HCMV), a member of herpes virus family, is associated with different cancers in humans, including breast and colorectal cancers.

Results

Conclusion The current study revealed that HCMV might have an oncogenic or oncomodulating activity on normal infected cells by different intracellular pathways.

Keywords Cytomegalovirus, oncogenic viruses, mrc-5, Waffergen, SmartChip Real-Time PCR System.
List of Abbreviation: HCMV =Human cytomegalovirus, MRC-5 = Medical research council-5

\section{Introduction}

$\mathrm{H}$ uman cytomegalovirus (HCMV) is a ubiquitous herpes virus that leads to a life-long persistence. The frequency of infection ranges from $50-100 \%$ in the community ${ }^{(1)}$. HCMV, species Human herpes virus 5, belongs to genus Cytomegalovirus, subfamily Betaherpesvirinae, family Herpesviridae. HCMV is a leading agent of complications of organ transplantation, congenital malformations, non-heterophil infectious mononucleosis, and life-threatening morbidities in immunocompromised individuals ${ }^{(2)}$. In addition, active and/or latent infection of HCMV has been recently linked with different human cancers including breast, colorectal, prostate, and malignant glioma cancers $^{(3)}$.

In vivo, HCMV is capable of infecting many cell types including fibroblasts, endothelial cells, smooth muscle cells, hepatocytes, macrophages and lymphocytes, and tumor cells (4). Medical research council-5 (MRC-5) cells are human diploid fibroblast cell line approved for vaccine production and favored for the routine propagation of HCMV ${ }^{(5)}$. MRC-5 cells have been used as a standard for over 30 years in basic research for HCMV infection. Moreover, MRC-5 cells have the ability of 46 cells doublings, enabling prudent exploit of these cells in assessing intracellular changes after exposure to $\mathrm{HCMV}^{(5)}$. 
The relationship between HCMV infection and cancer has been investigated for decades. Presence of HCMV DNA, mRNA, and its proteins in tumor tissues indicated a probable role of HCMV infection in the causation of several human malignancies (2). Moreover, sero-epidemiologic evidence added more linkage between HCMV and human cancers ${ }^{(6)}$. It was shown that HCMV can transform normal human embryonal cells in vitro ${ }^{(7)}$. Other studies reported that HCMV infection in normal rodent cells affects cellular genes that are critical for malignant transformation $(8,9)$. However, there is controversy on the carcinogenic effect of HCMV on normal cells. It was suggested the oncomodulation concept of HCMV, which refers to the capability of HCMV to preferentially infect tumor cells and enhance their malignant profile lead to a shift to a more malignant phenotype of tumor cells and tumor progression ${ }^{(10)}$. Several studies showed that the presence of HCMV in tumor cells but not in adjacent normal tissue was more than $90 \%$ of patients with certain malignancies, such as colon cancer, malignant glioma, prostate carcinoma, and breast cancer (11-14). Nevertheless, in the context of the oncogenic or oncomodulation scenarios, by all means, $\mathrm{HCMV}$, seems to have a direct or indirect role in carcinogenesis.

There have been numerous studies on the oncogenic and oncopromoting potential of HCMV on tumor cell lines such as neuroblastoma cell lines (15-17); however, no such coverage was done on the oncogenic potential of HCMV, if any, on normal cell lines such as MRC-5 cells using high throughput quantitative PCR microarray. Therefore, this study aimed at covering a different aspect of HCMV relationship with cancers as this study focused on the changes at genetic expression of normal cells, MRC- 5 cell line, as a response to HCMV infection. This approach is believed to shed light on HCMV oncogenic/ oncomodulating potential on normal cells rather than previously researched tumor cells. Hence, this study was designed to investigate the mechanisms of oncogenesis, or oncomodulation, if any, by HCMV on normal diploid cells by using a high throughput SmartChip quantitative real-time PCR microarray. This study explored 983 genes that may have a role in carcinogenesis and transformation of human cells and tried to give a complete map for the target genes which might be up- or down- regulated by this virus. This will facilitate the understanding of the possible oncogenic and/or oncomodulating mechanisms exerted by HCMV on human cells.

\section{Methods}

This study was conducted in multidiscipline laboratories of Kent State University. It is a single authored project funded by Kent State University, Ohio, USA and Fulbright organization and was conducted during the period from July $5^{\text {th }}$ to September $15^{\text {th }} 2012$.

\section{Cells and viruses}

MRC-5 human diploid fibroblasts passage 6 was received from American Tissue Culture Collection (ATCC CCL-171, USA). Cells were cultured in Eagle's minimum essential medium (EMEM) supplemented with Earle's salts containing $10 \%(\mathrm{v} / \mathrm{v})$ fetal calf serum, $1 \times 10^{6}$ IU/I penicillin, $120 \mathrm{mg} / \mathrm{l}$ streptomycin and 2 $\mathrm{mM}$ glutamine. Subcultivation ratio of CCL-171 was $1: 2$ to $1: 5$ and the medium renewal once every 5-6 days. Flasks of $75 \mathrm{qcm}$ were used in propagation of MRC- 5 cells and incubated at humid $37^{\circ} \mathrm{C}$ with $5 \% \mathrm{CO}_{2}$ incubator.

MRC-5 cells were subcultured by removing and discarding culture medium. Briefly by rinsing the cell layer with $0.25 \%(w / v)$ Trypsin $0.53 \mathrm{mM}$ EDTA solution to remove all traces of serum, which contains trypsin inhibitor. Then, 2.0 to $3.0 \mathrm{ml}$ of Trypsin-EDTA solution were added to flask and observe cells under an inverted microscope until cell layer is dispersed (usually within 5 to 15 minutes). Cells that are difficult to detach may be placed at $37{ }^{\circ} \mathrm{C}$ to facilitate dispersal. Afterwards, 6.0 to $8.0 \mathrm{ml}$ of EMEM complete growth medium were added and resultant cell suspension was 
aspirated by gently pipetting and appropriate aliquots of the cell suspension were added to new culture vessels and incubated at $37{ }^{\circ} \mathrm{C}$ until next subculturing ${ }^{(18)}$.

HCMV infections were performed using highpassage strain AD169, obtained from ATCC. About $1 \times 10^{5}$ cells of MRC- 5 were suspended in $1 \mathrm{ml}$ of cell-free AD169 suspension $\left(1 \times 10^{5}\right.$ $\mathrm{pfu} / \mathrm{ml}$ ) for 3 hours at multiplicity of infection (MOI) equal to 1 . Afterwards, infected MRC-5 cells were centrifuged at $3500 \mathrm{~g}$ for 5 minutes and pellet was resuspended in fresh EMEM medium; washing step was repeated 3 times. Then, HCMV-infected MRC- 5 cells were plated onto Corning ${ }^{\circledR}$ T75flasks 75 sq.cm flask for 4 weeks with weekly renewal of EMEM medium and cells subculturing. Cytopathic effects of HCMV were screened routinely for the confirmation of the persistence of HCMV infection.

Two sets of MRC-5 cells were grown for 4 weeks, the first set was infected with HCMV, AD169, virus and the second set was not infected. Stringent measures were pursued to separate two sets apart in order not mix infection. Vital cell count was performed at every freshening step for both sets. The vital count difference between two sets was not more than 7\%, being HCMV-infected cells of lower count. So, $7 \%$ difference in cell vitality was not considered significant factor that could alter genetic comparison between the two sets of cells.

\section{Flow cytometry analysis}

After 4-week interval of growth and viral propagation, HCMV- infected and noninfected MRC- 5 cells were harvested and transferred to $15 \mathrm{ml}$ tubes. All of the tubes were centrifuged at $300 \mathrm{~g}$ for 8 minutes. The supernatants were discarded and the pellets were washed two times by cold PBS. Then, pellets were resuspended in $70 \%$ ice-cold ethanol with PBS, $1: 10 \mathrm{v} / \mathrm{v}$. Then, all the supernatants were aspirated after centrifugation at $500 \mathrm{~g}$ for 8 min. The washing step by PBS was repeated and the supernatants were aspirated. A cell count was performed and the number of cells adjusted to $1 \times 10^{5}$ cell $/ \mathrm{ml}$ with cold PBS and then, $100 \%$ methanol was added and then stored at $-20{ }^{\circ} \mathrm{C}$ until staining. The method used was according to Jacobbergar and Lehman ${ }^{(19)}$. Briefly, after removal of fixative, the cells were resuspended in flourochromelabeled antibody to CMV early nuclear antigen using case-customized kit (Dako, Denmark, No. 1284) diluted in PBS- $130 \mathrm{mM} \mathrm{NaCl}, 15 \mathrm{mM}$ phosphate $(\mathrm{pH} 7.4)$, and 1:1 volume of heatinactivated normal goat serum with $0.004 \%$ Triton X-100 and $0.2 \%$ sodium azide. The antibody was incubated with the cells for 90 min at $37^{\circ} \mathrm{C}$ and washed 3 times in cold PBS. Then, MRC- 5 cells were incubated for 30 minutes at $37^{\circ} \mathrm{C}$ in $0.5 \mathrm{ml}$ of RNase A (Qiagen, Germany) and samples were then stored in the dark at $4{ }^{\circ} \mathrm{C}$ overnight. The assay was measured in duplicates for each sample. The percentage of CMV-infected cells was measured using CyAn ADP apparatus (BECKMAN COULTER, USA). The software Summit (V4.3) was used to analyze the flow cytometry results.

\section{SmartChip Real-Time PCR System}

SmartChip Human Oncology Gene Panel version 1.5.1 from (WaferGen, BIOSYSTEMS, Fremont, CA, U.S.A.) enables gene expression profiling of 4,128 reaction wells on a single sample using the SmartChip Nanodispenser (WaferGen, BIOSYSTEMS, Fremont, CA, USA). SmartChip panels are preloaded with preoptimized PCR primers that have been validated in both microliter- and nanoliterscale SYBRGreen real-time PCR experiments. The primers used to investigate 983 human oncogenesis-related genes in quadruplicate belonging to 16 functional groups (Table 1), 9 endogenous controls (Table 2) and 6 exogenous yeast controls. The SmartChip Human Oncology Gene Panel was used to measure differential gene expression from 0.5 $\mu \mathrm{g}$ of RNA of HCMV-infected MRC-5 cells versus that of non-infected MRC-5 cells; only 
significantly up- and down-regulated genes are displayed in this study.

Table 1. The gene families covered by high throughput Real-Time qPCR System using WaferGen SmartChip Human Oncology Gene Panel

\begin{tabular}{c}
\hline Gene Family \\
ADME* \\
Apoptosis \\
Cancer \\
Cell Cycle/Proliferation \\
Cardiovascular Disease \\
DNA damage repair \\
Drug Target \\
G-protein coupled receptor \\
Growth factor \\
Homeostasis/Metabolism \\
Inflammation \\
Kinase \\
Proteinase \\
Signal Transduction \\
Transcription Factor \\
NeuroDisease/Phosphotase
\end{tabular}

Table 2. Endogenous internal control (reference genes) used in SmartChip Real-Time PCR System: all of reference genes were amplified and used successfully for normalization

\begin{tabular}{cccccccc}
\hline Primer & Functional & failed & Total & Ct & Ct SD & Tm & Tm SD \\
\hline TAF10 & 4 & 0 & 4 & 25.34 & 0.359 & 79.0 & 0.155 \\
GUSB & 4 & 0 & 4 & 30.58 & 0.320 & 82.2 & 0.099 \\
TAF11 & 4 & 0 & 4 & 28.38 & 0.763 & 81.4 & 0.164 \\
HPRT & 4 & 0 & 4 & 26.69 & 0.193 & 81.9 & 0.101 \\
PPIA & 4 & 0 & 4 & 21.43 & 0.078 & 85.0 & 0.068 \\
HMBS & 3 & 0 & 3 & 29.66 & 1.25 & 83.2 & 0.088 \\
ACTB & 4 & 0 & 4 & 25.33 & 0.750 & 87.2 & 0.178 \\
B2M & 4 & 0 & 4 & 21.94 & 0.129 & 85.4 & 0.085 \\
TAF1L & 4 & 0 & 4 & 29.00 & 1.10 & 83.1 & 0.058 \\
\hline
\end{tabular}

\section{RNA extraction}

RNA extraction was done according to the guidelines and protocols provided by Wafergen Bio, USA. $1 \times 10^{6}$ MRC- 5 cells were harvested and transferred to $15 \mathrm{ml}$ tubes. After centrifuging the tubes at $300 \mathrm{~g}$ for 5 minutes, the supernatants were discarded. The pellets were resuspended in PBS and were washed for 3 times. Total RNA was isolated using RNeasy Mini Kit (Qiagen, Germany: Cat No./ID: 74104) Briefly, according to the manufacturer's protocol for RNA isolation from cell culture, cells were resuspended in $700 \mu$ of lysis buffer (Buffer TR) with vigorous vortexing to inactivate cellular RNases together with cell lysis. Later, the lysed cells were transferred to homogenization columns. The columns were centrifuged at $10.000 \times \mathrm{g}$ 
for $2 \mathrm{~min}$. The flow-though was saved and equal volume of $80 \%$ ethanol $(700 \mu \mathrm{l})$ was added. The lysed cells were transferred into RNA binding columns that were centrifuged at $10.000 \times \mathrm{g}$ for $1 \mathrm{~min}$ and the flow-through was discarded. Columns were washed using washing buffer and then DNA fragments were removed by DNase I treatment. Further centrifugation at $10.000 \times \mathrm{g}$ for $1 \mathrm{~min}$ was done to remove any traces of used buffers. Total RNA was collected by placing the columns into new $1.5 \mathrm{ml}$ microtubes with 60 $\mu l$ RNase-free water addition and standing for $1 \mathrm{~min}$. The microtubes were centrifuged at $10.000 \times \mathrm{g}$ for 1 minute.

RNA quality and quantity were determined by Life Science UV/Vis Spectrophotometer, DU Series 700 (BECKMAN COULTER, USA). RNA concentration used in downstream experiments ranged from 503 to $524 \mathrm{ng} / \mu \mathrm{l}$. Moreover, total RNA quality was checked by Agilent 2100 Bioanalyzer (Agilent, USA) and RNA integrity number (RIN) was measured. RIN of total RNA was 9.1 and passed the quality control limit for running downstream experiments.

\section{Synthesis of CDNA}

The reverse-transcription of up to $0.5 \mu \mathrm{g}$ of the isolated MRC- 5 cell's RNA was done using iScriptTM CDNA Synthesis Kit (BIO-RAD, Hercules, Canada). According to the manufacturer's protocol, $4 \mu$ l of $5 \times$ iScript reaction mix were mixed with $1 \mu$ iScript reverse transcriptase and $15 \mu$ of RNA template in $1.5 \mathrm{ml}$ microtubes to give final volume of $20 \mu \mathrm{l}$ per reaction. The complete reaction mix was incubated for 5 min at $25^{\circ} \mathrm{C}$ then for $30 \mathrm{~min}$ at $42{ }^{\circ} \mathrm{C}$. The incubation temperature was increased to $85^{\circ} \mathrm{C}$ for $5 \mathrm{~min}$. Finally, cDNA was stored at $-80^{\circ} \mathrm{C}$ for qRT-PCR reaction.

\section{Real-time quantitative RT-PCR}

Real-time quantitative $P C R$ reaction was conducted according to the procedure validated by (Wafergen Bio, USA) using the
SmartChip human oncology panel version 1.5.1. These chips were preloaded with primer content optimized for performance with the high throughput Real-Time PCR System. The SmartChip Nanodispenser (Wagergen Bio, USA) was used to dispense the sample, combined with master mix and controls, under vacuum into the SmartChip. Five hundred (500) ng of starting sample of cDNA yielded cDNA equivalent of $96 \mathrm{pg}$ of sample per well. Once loaded with sample, the SmartChip was placed into the WaferGen SmartChip Cycler Nanodispenser (Wagergen Bio, USA). The SmartChip Real-Time PCR system employs a QPCR reaction compatible with SYBR green I DNA binding dye. Results were reported in the form of $\mathrm{Ct}$ (threshold cycles), Tm (melting temperatures), and amplicon melting curve analyses.

Primers used are based on criteria such as specificity, insensitivity to sequence polymorphisms, amplicon size, and minimization of primer artifacts. Primer specificity was determined using (a) melting curve analysis of amplicon product, (b) gel electrophoresis analysis of amplicons and (c) sequence verification of the amplicons. The up- and down- regulation of genes were analyzed by SmartChip Software (Wafergen Bio, USA). The sensitivity of real-time PCR is 20-30 copies of RNA per well with specificity of genes discrimination $<90 \%$ homology. To keep precision of readings, standard deviation $<0.25$ $\mathrm{Ct}$ between replicates was used. For valid runs, all primers shared the same or close-by Tm and amplicon size and no primer dimers or primer secondary structures were allowed. Thermal cycling of primers was $95 \mathrm{C}$ for $180 \mathrm{sec}$ once, and for 40 cycles: $95 \mathrm{C}$ for $60 \mathrm{sec}$, and 60 $C$ for $70 \mathrm{sec}$ with amplicons size ranged from 80 to 120 nucleotides. Automatic screening for low efficiency wells turned out to be zero and PCR efficiency for all primers was measured and taken into account for calculating fold changes in genes expression. All-means normalization method, where the means of all expressed genes are employed, was used in 
the current study. In addition, six exogenous yeast controls were used (WGBS-YCF1-6); at least four of them should be detected and be linear in proportion. At each run two negative tissue controls (NTC), chip no. 34565 and 35935, and two positive tissue controls, brain tissue (PTC), chip no. 34576 and 35939, were used.

The fold change calculation used was based on the Comparative $\mathrm{Ct}$ Method. The comparative $C t$ Method is also known as the 2- $\Delta \Delta C t$ method and as follows: $\Delta \Delta \mathrm{Ct}=\Delta \mathrm{Ct}$ treated $\Delta \mathrm{Ct}$ untreated, where: $\Delta \mathrm{Ct}$ treated $=\mathrm{Ct}$ treated - All Mean treated and $\Delta C$ t untreated $=\Delta C \mathrm{Ct}$ untreated - All Mean untreated. The significant up/down regulated genes are those genes with at least two fold change.

\section{Data analysis}

The data in the current study are shown as mean $\pm 2 S D$. The data analysis was conducted by using SPSS software version (11.0.0.1). Simple percentage calculation was used to obtain the \% of HCMV-infected cells by Flow cytometry assay. For real-time qPCR, SmartChip qPCR software exerted all data analysis. $\mathrm{P}$ values less than 0.05 were considered significant.

\section{Results}

Percentage of MRC-5 cells infected with HCMV

After 4 weeks propagation of HCMV, AD-169 strain, in MRC-5 cells, the percentage of infected cells was measured by using flow cytometry method. The percentage of HCMVinfected MRC- 5 cells was shown to be $94.1 \%$. This finding indicated that MOI 1 of MRC-5 cells with AD-169 strain of HCMV is sufficient to attain near complete infection of all exposed cells after 4 weeks of viral propagation. This step is essential to confirm the homogeneity of real-time qPCR results of gene expression profiling.

\section{SmartChip Real-Time PCR System}

After the completion of real-time PCR assay, descriptive statistics of SmartChip panel technical results are shown in Table 3 and Figure 1 . In addition, the setting values used for SmartChip RT-PCR panel are shown in Table 4.

Table 3. The technical results of the SmartChip oncogenic panel used in the current study

\begin{tabular}{lr}
\hline Name & Value \\
\hline Total wells & 4128 \\
\hline No amplification & 1648 \\
Curve fit failed & 232 \\
With curves & 2248 \\
Bad R2 & 0 \\
Low efficiency & 0 \\
High efficiency & 0 \\
Ct is small & 0 \\
Ct is large & 136 \\
Low saturation & 0 \\
Saturation/Baseline ratio is low & 1 \\
Multiple peaks & 62 \\
Multimodal Tm's & 14 \\
Informative & 302 \\
Replicates without curves & 347 \\
\hline
\end{tabular}



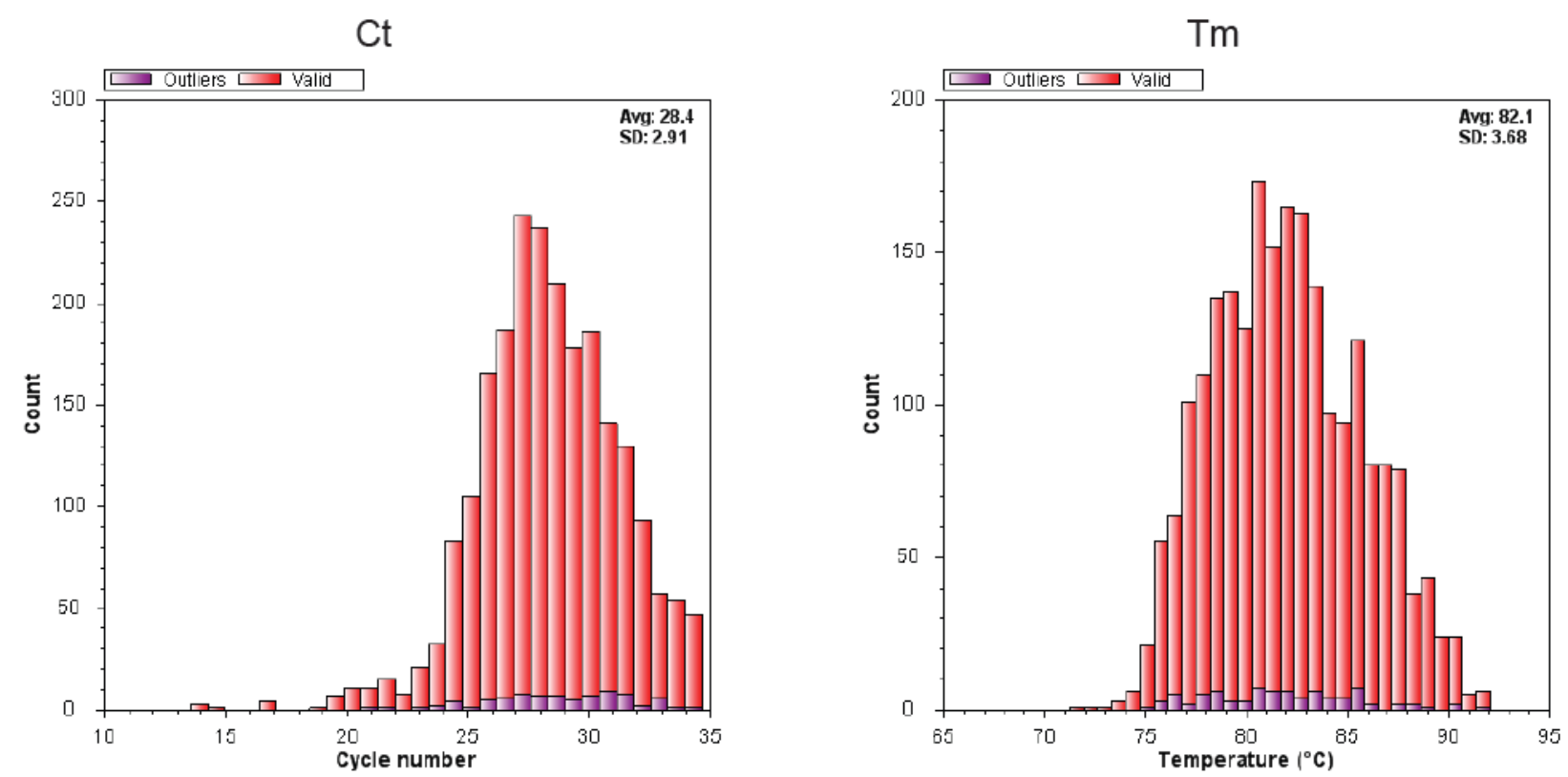

Figure 1. Histogram of the frequency of $\mathrm{Ct}$ and $\mathrm{Tm}$ for SmartChip RT PCR showing that $\mathrm{Ct} \mathbf{2 5}$ to 30 cycles and Tm 75 to $85 \mathrm{C}$ were dominant among different primer sets used for both HCMV infected and non-infected SmartChiponcopanels

Table 4. The settings and values of the RT-PCR SmartChip assay

\begin{tabular}{lr}
\hline Threshold & Value \\
\hline Ct max deviation & 0.5 \\
Fail curve based on R2 & 0.99 \\
Grubbs confidence & 0.05 \\
Grubbs Min SD & 0.25 \\
High Ct & 33 \\
High efficiency & 3 \\
Informative replicates SD & 0.6 \\
Low Ct & 5 \\
Low efficiency & 1.5 \\
Low saturation & 1000 \\
Low saturation/baseline ratio & 1.8 \\
Max Baseline drift & 21 \\
Max Ct & 35 \\
Max efficiency & 3.5 \\
Melt multimodel & 1 \\
Melt peak left & 0.6 \\
Melt peak right & 0.3 \\
Min amplification & 500 \\
Min efficiency & 1.5 \\
No amplification ratio & 2 \\
Point used for curve fit & 15 \\
R2 & 0.99 \\
\hline
\end{tabular}


Detection of the up- and down-regulation of gene expression by SmartChip Real-time PCR System

The quantitative analysis by real-time PCR revealed a complete picture regarding the upor down-regulated genes in HCMV-infected MRC- 5 cells compared to that of non-infected cells. The results showed that almost all genes were expressed in a very close level (less than 2 folds) while only 15 genes were upregulated and 5 genes were downregulated (Table 5; Figure 2). Although the number of genes that showed differential expression was totally 20 , this variation has its own importance due to the association of the affected genes to critical cell functions including cancer, apoptosis and cell cycle regulation. It is noteworthy to mention that most of the genes up- or downregulated in the current study belong to gene families of multiple functions (Table 6), for example a gene family is related to inflammation, cancer, signal transduction and apoptosis at the same time.

\section{Discussion}

MRC-5 cell line was chosen and AD-169 strain of HCMV was used in order to propagate HCMV in normal diploid cells for 4 weeks ensuring long-term infection that is necessary to observe any variation in genes expression. The limitation of this study is the same as its advantage, namely MRC- 5 cells. Breast, colon and prostate tissue cells are more prone to cancers where HCMV is implicated. However, CMV grows slowly in other cell lines and the initial trials of this study for infecting HCMV in cell lines other than MRC-5 turned out with shorter periods of HCMV propagation as well as much higher cell death [data not shown]. Hence, MRC- 5 cells were preferred over other types of cells.

Table 5. Fold change and Log2 Fold change of the up- and down-regulated gene expression in HCMV-infected MRC-5 cells compared to HCMV non-infected cells

\begin{tabular}{cccc}
\hline Primer & $\boldsymbol{\Delta} \boldsymbol{\Delta C \text { Ct }}$ & Fold Change & Log2(Fold Change) \\
\hline SCGB1A1 & -3.927 & 15.211 & 3.927 \\
MAP2K3 & -3.215 & 9.285 & 3.215 \\
ITGB3 & -2.287 & 4.879 & 2.287 \\
TGFB1 & -2.253 & 4.767 & 2.253 \\
PTN & -1.890 & 3.708 & 1.890 \\
MMP2 & -1.889 & 3.704 & 1.889 \\
AKT1 & -1.770 & 3.410 & 1.770 \\
AKT2 & -1.757 & 3.381 & 1.757 \\
BCL2L10 & -1.756 & 3.378 & 1.756 \\
CKS1B & -1.400 & 2.639 & 1.400 \\
SERPINB4 & -1.311 & 2.482 & 1.311 \\
CASP4 & -1.164 & 2.240 & 1.164 \\
TOLLIP & -1.108 & 2.156 & 1.108 \\
BCL-2 & -1.078 & 2.111 & 1.078 \\
SERPINB5 & -1.003 & 2.004 & 1.003 \\
STAT3 & 1.020 & 0.493 & -1.020 \\
BAK1 & 1.031 & 0.489 & -1.031 \\
BLM & 1.031 & 0.489 & -1.031 \\
RB1 & 1.152 & 0.429 & -1.223 \\
IGF2R & 1.194 & 0.211 & -2.248 \\
\hline
\end{tabular}




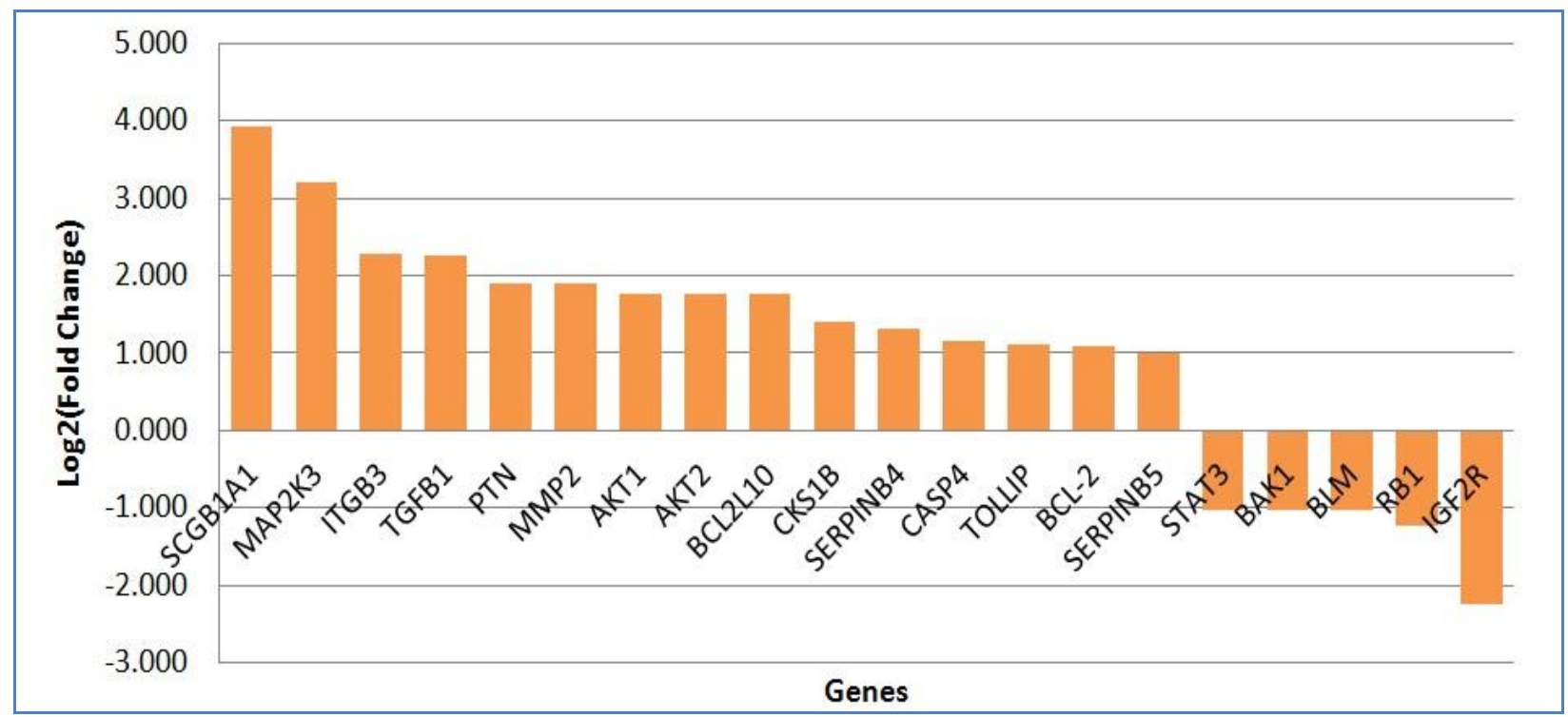

Figure 2. A diagram showing 15 up-regulated and 5 down-regulated gene expression in HCMVinfected MRC- 5 cells compared to HCMV non-infected cells

\section{Table 6: Gene families and gene functions/pathways involved in the differentially expressed genes between HCMV-infected and HCMV non-infected MRC- 5 cells}

\begin{tabular}{|c|c|c|c|c|c|}
\hline $\begin{array}{l}\text { Up- } \\
\text { regulated } \\
\text { Gene }\end{array}$ & Gene family & $\begin{array}{l}\text { Gene product related function/pathway/ } \\
\text { By Genecards ( }{ }^{21)}\end{array}$ & $\begin{array}{l}\text { Down- } \\
\text { regulate } \\
\text { d gene }\end{array}$ & Gene family & $\begin{array}{l}\text { Gene product related } \\
\text { function/pathway/ } \\
\text { By Genecards ( }\end{array}$ \\
\hline SCGB1A1 & Inflammation & $\begin{array}{l}\text { SCGB1A1 (Secretoglobin, Family } 1 \mathrm{~A} \text {, } \\
\text { Member } 1 \text {. Among its related pathways are } \\
\text { FOXA1 transcription factor network and } \\
\text { Prostaglandin Synthesis and Regulation. this } \\
\text { gene product binds to phospholipase A2 } \\
\text { inhibitor activity }\end{array}$ & STAT3 & $\begin{array}{l}\text { Cancer; } \\
\text { Inflamation; } \\
\quad \text { Signal } \\
\text { Transduction; } \\
\text { Transcription } \\
\quad \text { Factor; }\end{array}$ & $\begin{array}{l}\text { STAT3 (Signal Transducer And Activator } \\
\text { Of Transcription } 3 \text { (Acute-Phase } \\
\text { Response Factor)) is a Protein Coding } \\
\text { gene. Diseases associated with STAT3 } \\
\text { include hyper ige syndrome and hyper- } \\
\text { ige recurrent infection syndrome. } \\
\text { Among its related pathways are } \\
\text { Immune System and Signaling by GPCR }\end{array}$ \\
\hline MAP2K3 & $\begin{array}{l}\text { Kinase; Signal } \\
\text { Transduction; }\end{array}$ & $\begin{array}{l}\text { MAP2K3 (Mitogen-Activated Protein Kinase } \\
\text { Kinase } 3 \text { ) is a Protein Coding gene. Among } \\
\text { its related pathways are MAPK signaling } \\
\text { pathway and Immune System. GO } \\
\text { annotations related to this gene include } \\
\text { transferase activity, transferring } \\
\text { phosphorus-containing groups and protein } \\
\text { tyrosine kinase activity }\end{array}$ & BAK1 & Apoptosis & $\begin{array}{l}\text { BAK1 (BCL2-Antagonist/Killer 1) is a } \\
\text { Protein Coding gene. Diseases } \\
\text { associated with BAK1 include benign } \\
\text { mammary dysplasia and chronic } \\
\text { gonococcal salpingitis. Among its } \\
\text { related pathways are Apoptotic } \\
\text { Pathways in Synovial Fibroblasts and } \\
\text { ERK Signaling }\end{array}$ \\
\hline ITGB3 & $\begin{array}{l}\text { Cancer; } \\
\text { Cardiovascular } \\
\text { Disease }\end{array}$ & $\begin{array}{l}\text { ITGB3 (Integrin, Beta 3, Glycoprotein IIIa). } \\
\text { Among its related pathways are PI3K-Akt } \\
\text { signaling pathway and Immune System }\end{array}$ & BLM & $\begin{array}{l}\text { DNA Damage } \\
\text { Repair }\end{array}$ & $\begin{array}{l}\text { BLM (Bloom Syndrome, RecQ Helicase- } \\
\text { Like) is a Protein Coding gene. Diseases } \\
\text { associated with BLM include bloom } \\
\text { syndrome and Werner syndrome. } \\
\text { Among its related pathways are Cell } \\
\text { Cycle, Mitotic and Integrated Pancreatic } \\
\text { Cancer Pathway. GO annotations } \\
\text { related to this gene include nucleic acid } \\
\text { binding and ATPase activity }\end{array}$ \\
\hline TGFB1 & $\begin{array}{l}\text { ADME; } \\
\text { Apoptosis; } \\
\text { Cancer; } \\
\text { Cardiovascular } \\
\text { Disease; } \\
\text { Inflamation; } \\
\text { Signal } \\
\text { Transduction; }\end{array}$ & $\begin{array}{l}\text { TGFB1 (Transforming Growth Factor, Beta 1) } \\
\text { is a Protein Coding gene. Diseases } \\
\text { associated with TGFB1 include camurati- } \\
\text { engelmann disease and cystic fibrosis. } \\
\text { Among its related pathways are MAPK } \\
\text { signaling pathway and Signaling by GPCR }\end{array}$ & RB1 & $\begin{array}{l}\text { Cell cycle } \\
\text { checkpoint }\end{array}$ & $\begin{array}{l}\text { RB1 (Retinoblastoma } 1 \text { ) is a tumor } \\
\text { supressor protein Coding gene. } \\
\text { Diseases associated with RB1 include } \\
\text { retinoblastoma and familial } \\
\text { retinoblastoma. Among its related } \\
\text { pathways are Pathways in cancer and } \\
\text { Glioma. }\end{array}$ \\
\hline
\end{tabular}




\begin{tabular}{|c|c|c|c|c|c|}
\hline PTN & $\begin{array}{l}\text { Cancer; } \\
\text { Cardiovascular } \\
\text { Disease; } \\
\text { Inflamation; }\end{array}$ & $\begin{array}{l}\text { PTN (Pleiotrophin) is a Protein Coding gene. } \\
\text { Among its related pathways are NF-KappaB } \\
\text { Family Pathway and Apoptotic Pathways in } \\
\text { Synovial Fibroblasts. }\end{array}$ & IGF2R & Growht factor & $\begin{array}{l}\text { IGF2R (Insulin-Like Growth Factor } 2 \\
\text { Receptor) is a Protein Coding gene. } \\
\text { Diseases associated with IGF2R include } \\
\text { hepatocellular carcinoma. Among its } \\
\text { related pathways are Apoptotic } \\
\text { Pathways in Synovial Fibroblasts and } \\
\text { GPCR Pathway. }\end{array}$ \\
\hline MMP2 & $\begin{array}{c}\text { Cancer; } \\
\text { Cardiovascular } \\
\text { Disease }\end{array}$ & $\begin{array}{l}\text { MMP2 (Matrix Metallopeptidase } 2 \text { ) is a } \\
\text { Protein Coding gene. Among its related } \\
\text { pathways are Developmental Biology and } \\
\text { Pathways in cancer. }\end{array}$ & & & \\
\hline AKT1 & $\begin{array}{c}\text { ADME; } \\
\text { Apoptosis; } \\
\text { Cancer; } \\
\text { Cardiovascular } \\
\text { Disease; G- } \\
\text { Protein Coupled } \\
\text { Receptor; } \\
\text { Inflamation; } \\
\text { Kinase; Signal } \\
\text { Transduction; }\end{array}$ & $\begin{array}{l}\text { AKT1 (V-Akt Murine Thymoma Viral } \\
\text { Oncogene Homolog 1) is a Protein Coding } \\
\text { gene. Diseases associated with AKT1 include } \\
\text { breast adenocarcinoma and proteus } \\
\text { syndrome, somatic. Among its related } \\
\text { pathways are PI3K-Akt signaling pathway } \\
\text { and PI3K/AKT Signaling in Cancer }\end{array}$ & & & \\
\hline AKT2 & $\begin{array}{c}\text { Signal } \\
\text { Transduction }\end{array}$ & $\begin{array}{c}\text { AKT2 (V-Akt Murine Thymoma Viral } \\
\text { Oncogene Homolog 2) is a Protein Coding } \\
\text { gene. Among its related pathways are PI3K- } \\
\text { Akt signaling pathway and PI3K/AKT } \\
\text { Signaling in Cancer. An important paralog of } \\
\text { this gene is AKT1. }\end{array}$ & & & \\
\hline BCL2L10 & Apoptosis & $\begin{array}{c}\text { BCL2L10 (BCL2-Like } 10 \text { (Apoptosis } \\
\text { Facilitator)) is a Protein Coding gene. } \\
\text { Diseases associated with BCL2L10 include } \\
\text { prostatic cyst. Among its related pathways } \\
\text { are Apoptosis (WikiPathways) and Apoptosis } \\
\text { and Autophagy. }\end{array}$ & & & \\
\hline CKS1B & Kinase & $\begin{array}{l}\text { CKS1B (CDC28 Protein Kinase Regulatory } \\
\text { Subunit 1B) is a Protein Coding gene. Among } \\
\text { its related pathways are Pathways in cancer } \\
\text { and Cell Cycle, Mitotic. }\end{array}$ & & & \\
\hline SERPINB4 & Angiogenesis; & $\begin{array}{l}\text { SERPINB4 (Serpin Peptidase Inhibitor, Clade } \\
\text { B (Ovalbumin), Member 4) is a Protein } \\
\text { Coding gene. Diseases associated with } \\
\text { SERPINB4 include inverted papilloma and } \\
\text { tongue squamous cell carcinoma. Among its } \\
\text { related pathways are Amoebiasis }\end{array}$ & & & \\
\hline CASP4 & $\begin{array}{c}\text { Apoptosis, Drug } \\
\text { target }\end{array}$ & $\begin{array}{c}\text { CASP4 (Caspase 4, Apoptosis-Related } \\
\text { Cysteine Peptidase) is a Protein Coding } \\
\text { gene. Diseases associated with CASP4 } \\
\text { include hepatitis c virus. Among its related } \\
\text { pathways are Immune System and } \\
\text { Apoptotic Pathways in Synovial Fibroblasts }\end{array}$ & & & \\
\hline TOLLIP & $\begin{array}{l}\text { Inflamation; } \\
\text { Signal } \\
\text { Transduction }\end{array}$ & $\begin{array}{l}\text { TOLLIP (Toll Interacting Protein) is a Protein } \\
\text { Coding gene. Diseases associated with } \\
\text { TOLLIP include lymphoproliferative } \\
\text { syndrome, x-linked, } 1 \text {. Among its related } \\
\text { pathways are Immune System and } \\
\text { Interleukin receptor SHC signaling. }\end{array}$ & & & \\
\hline $\mathrm{BCL}-2$ & Apoptosis & $\begin{array}{l}\text { BCL2 (B-Cell CLL/Lymphoma 2) is a Protein } \\
\text { Coding gene. Diseases associated with BCL2 } \\
\text { include follicular lymphoma and } \\
\text { intravascular large b-cell lymphoma. Among } \\
\text { its related pathways are PI3K-Akt signaling } \\
\text { pathway and Immune System. }\end{array}$ & & & \\
\hline SERPINB5 & Angiogenesis & $\begin{array}{l}\text { SERPINB5 (Serpin Peptidase Inhibitor, Clade } \\
\text { B (Ovalbumin), Member 5) is a Protein } \\
\text { Coding gene. Diseases associated with } \\
\text { SERPINB5 include mandibular cancer and } \\
\text { syringoma. Among its related pathways are } \\
\text { MicroRNAs in cancer and Angiogenesis (CST) }\end{array}$ & & & \\
\hline
\end{tabular}


Using high throughput platforms of real-time qPCR is superior on using gene expression microarrays. The reason is that high throughput real-time qPCR is highly quantitative and precise, unlike that in gene expression microarrays which are precise but not quantitative (20). The current study screened which genes are differentially expressed when MRC-5 cells are infected with HCMV. Results showed that 15 genes were upregulated in HCMV-infected cells belonging to collectively 11 gene families namely, inflammation, kinase, signal transduction, cancer, cardiovascular disease, ADME, apoptosis, cancer, G-protein coupled receptor, angiogenesis, and drug target. In addition, expression of 5 genes were downregulated in HCMV-infected cells belonging collectively to 9 gene families namely, kinase, apoptosis, DNA damage repair, cell cycle checkpoint, cancer, inflammation, signal transduction, transcription factor, and growth factor.

Taking each gene family separately for the upregulated genes, five genes have inflammation downstream effect including SCGB1A1, TGFB1, PTN, AKT1, and TOLLIP and six genes showing kinase/signal transduction effect namely, MAP2K3, TGFB1, AKT1, AKT2, $\mathrm{CKS1B}$, and TOLLIP and five genes belong to cancer promoting family of genes including ITGB3, TGFB1, PTN, MMP2, and AKT1 and five genes related to apoptosis including TGFB1, AKT1, BCL2L10, CAPS4, BCL-2 and two genes related to angiogenesis namely SERPINB4 and SERPINB5.

Gene function analysis of the upregulated genes shows an important observation that the majority of the gene functions are oncogenic and/or oncopromoting directly or indirectly. SCGB1A1 gene is a Secretoglobin, Family 1A, Member 1; among its related pathways are FOXA1 transcription factor network and Prostaglandin Synthesis and Regulation ${ }^{(21)}$. So, this gene is pro-inflammatory and was upregulated more than 15 folds indicating HCMV induce inflammation through this gene.
It is well known that inflammation is one mechanism of cancer promotion and initiation (22) especially in long lasting infections (23). Another gene is associated with inflammation and cancer, PTN which is a Pleiotrophin; among its related pathways are NF-KappaB Family Pathway and Apoptotic Pathways (21). Pleiotrophin, PTN, gene was found to elicit protumorigenic effects through its receptor, protein tyrosine phosphatase receptor, Z1 (PTPRZ1) (24). Moreover, mitogen-activated protein kinase (MAPK) family were found to be likely effectors of PTN signaling and is associated with ovarian cancer ${ }^{(24)}$. Another gene, TOLLIP (Toll Interacting Protein), is also associated with inflammation and signal transduction; among its related pathways are immune system and interleukin receptor SHC signaling ${ }^{(21)}$. TOLLIP has been linked strongly with lung, prostate, breast cancers and melanoma ${ }^{(25)}$; and related to activation of interleukin-1 (IL-1) receptor (IL-1R), Toll-like receptor 2 (TLR2), and TLR4 which trigger NFkappaB and MAPK-dependent signaling, thereby initiating immune responses and maybe tumors ${ }^{(26)}$.

MAP2K3 gene is a MAPK, Kinase 3; involved in MAPK signaling pathway and immune system. MAPK pathway has a clear role in carcinogenesis ${ }^{(21)}$. This kinase is activated by mitogenic and environmental stress, and participates in the MAPK-mediated signaling cascade ${ }^{(27,28)}$. Expression of $\mathrm{K}$-ras oncogene is found to result in the accumulation of the active form of this kinase, which thus leads to the constitutive activation of MAPK14, and confers oncogenic transformation of primary cells ${ }^{(29)}$. It is well known that K-ras expression is strongly associated with carcinogenesis ${ }^{(30)}$. Therefore, HCMV might acts like a K-ras oncogene in inducing transformation. Another upregulated gene involved in MAPK pathway was TGFB1, which also triggers local immune suppression (31) and induces cancer (32). Enhanced expression of TGFB1 was found to enhance several cancer-related events such as 
cell division, cell motility, and the development of new blood vessels, angiogenesis. The TGF $\beta-1$ protein is abnormally overexpressed in certain types of prostate, breast, colon, lung, and bladder cancers ${ }^{(33)}$.

One of the interesting findings of the current study is that three upregulated genes are involved in PI3K/Akt pathway, which has a wellknown role in carcinogenesis ${ }^{(34)}$. These genes are ITGB3, AKT1 and AKT2. Phosphatidylinositol 3 kinase, or PI3K activates Akt, which modulates the function of numerous substrates involved in the regulation of cell survival, cell cycle progression and cellular growth ${ }^{(21,34)}$. It has been shown that PI3K/Aktsignalling pathway components are frequently altered in human cancers ${ }^{(35)}$. It was found that survival signals counteracting apoptosis induced by several receptors are mediated mainly by PI3K/Akt; hence this pathway was found to decisively contribute to the resistant phenotype of many cancers ${ }^{(34,36)}$. The PI3K/Akt pathway is involved in many of the mechanisms targeted by new anticancer drugs such as Everolimus by Novartis, which is an immunosuppressant and recently approved in treatment of hormone therapy-resistant estrogen receptor-positive breast cancer by blocking some links in the activated PI3K/Akt pathway ${ }^{\text {(37). }}$.

Regarding apoptosis-related genes that were upregulated after HCMV infection, the picture is complex and not so clear. Two upregulated genes induce apoptosis process, which are CASP4 and BCL2L10 while the third one is antiapoptotic, BCL-2. This needs further investigations by separate experiments in order to elucidate the net effect of apoptosis exerted by HCMV on normal cells.

Another upregulated gene was Matrix Metallopeptidase 2 (MMP-2) gene encoding type IV collagenase. Among its related pathways are developmental biology and pathways in cancer (21). MMP-2 and MMP-9 secretion is elevated in several types of human cancers and their elevated expression has been associated with poor prognosis ${ }^{(38)}$. The major implications of MMPs in cancer progression is their role in extracellular matrix degradation, which allows cancer cells to migrate out of the primary tumor to form metastases ${ }^{(39)}$.

Serpin Peptidase Inhibitor, SERPIN, B4/B5 are two genes mildly upregulated by HCMV infection and both are related to enhanced angiogenesis. SERPINB4 is associated with inverted papilloma and tongue squamous cell carcinoma. SERPINB5 (Serpin Peptidase Inhibitor, Clade B Member 5) is associated with mandibular cancer. Among its related pathways are MicroRNAs in cancer and angiogenesis ${ }^{(21)}$. In addition, elevated levels of these two genes are associated with inflammatory reactions in atopic dermatitis and psoriasis (40). Hence, these genes exert two mechanisms that might promote cancer status namely induction of inflammation and angiogenesis.

The last of the upregulated genes is CKS1B which is $\mathrm{CDC} 28$ protein kinase regulatory subunit 1B; among its related pathways are pathways in cancer and cell cycle, and mitosis (21). The expression of CKS1B is elevated in multiple cancers, including breast cancer, lymphoma, myeloma, colon cancer, prostate cancer, and lung cancer ${ }^{(41)}$. Amplification and overexpression of CKS1B are strongly associated with lymph node metastasis and poor prognosis in breast and salivary cancer (42). Generally, CKS1B is an essential factor in facilitating Skp2-dependent degradation of p27 (41).

There are only 5 downregulated genes after exposure to HCMV infection, which are: STAT3 (cancer, inflammation, signal transduction and transcription factor), BAK1 (pro-apoptotic), BLM (DNA damage repair), RB1 (cell cycle checkpoint), and IGF2R (growth factor) ${ }^{(21)}$.

Downregulation of expression of all above mentioned genes except for STAT3 is of oncogenic, oncopromoting or oncomodulating effect (21). Downregulation of BAK1 (BCL2antagonist/killer 1) lowers the antagonism of BAK1 to BCL-2 leading to less apoptotic potential of the cells favoring cell 
carcinogenesis indirectly ${ }^{(43)}$. For RB1 gene, it encodes Retinoblastoma 1which is an essential tumor suppressor protein that regulates cell cycle progression; lowered expression of RB1 product is strongly associated with cancer ${ }^{(44)}$ as cell proceeds to mitosis without rate limiting control by the tumor suppressor protein, retinoblastoma. For BLM gene, it provides instructions for making RecQ helicases, enzymes that attach to DNA and unwind the double helix of the DNA molecule. This unwinding is necessary for several processes in the cell nucleus, including copying DNA in preparation for cell division and repairing damaged DNA (21). Because RecQ helicases helps maintain the structure and integrity of DNA, they are known as the "caretakers of the genome". Hence, decreased expression of BLM helps damage DNA molecule and facilitates carcinogenesis in long term infection of HCMV $(45,46)$. For IGF2R (Insulin-Like Growth Factor 2 Receptor), diseases associated with IGF2R include hepatocellular carcinoma and in breast cancer ${ }^{(21)}$. IGF2R is a negative regulator of cell growth and a putative tumor suppressor gene and the regulation of M6P/IGF2r levels is critical in breast physiology and lowered expression of IGF2R is associated with various aspects of breast cancer ${ }^{(47)}$. The role of the differential expression of IGF2R between HCMV infected and non-infected seems important as it was downregulated by more than 4 folds and because of its important role in normal physiology of breast tissue ${ }^{(47)}$ where $\mathrm{HCMV}$ is strongly linked to breast cancer.

In regard to STAT3 gene (signal transducer and activator of transcription 3 ), it comprises a family of cytoplasmic transcription factors that mediates intracellular signaling and nucleus transcriptional activity (21). Constitutive activation of STAT3 was shown in a wide variety of human tumors, including hematological malignancies, head and neck, breast, lung, and gastric cancers ${ }^{(48)}$. Unlike other differentially expressed genes of this study, lowered expression of this gene seems of protective role against cancer. However, what is the exact role of the lowered STAT3 in HCMV infection is not yet clear. This needs further investigation. Nevertheless, one gene with anticancer activity versus numerous genes with cancerous activity seems of inferior effect. So taken together, this study has concluded for the first time, that the effect of HCMV infection on the level of expression of 983 genes related directly or indirectly to oncogenesis was studied in normal non-cancerous cells. In this study, HCMV infection stimulated expression of several genes that might trigger or promote cancer by different mechanisms. Most important mechanisms observed were activating MAPK and PI3K/AKT pathways, inducing inflammation, inhibiting apoptosis, inducing angiogenesis, and inhibiting tumor suppressor proteins. Activation of MAPK and PI3K/AKT pathways and lowered tumor suppressor activity implies to tumor initiating more than tumor promoting effect, while inducing angiogenesis, inflammation, inhibiting apoptosis, and inducing extracellular matrix proteases implies to tumor promoting/modulating effect more than tumor initiating effect. This study is believed to direct the coming studies on investigating deeply the role of differentially expressed genes by HCMV infection. This can shed light on the exact mechanisms and pathways that HCMV might exert to initiate or promote/modulate human cancers.

\section{Acknowledgement}

This study was facilitated by the high scale and well-equipped laboratories of Kent State University. In addition, WaferGen, BIOSYSTEMS, Fremont, CA, U.S.A. Company kindly waived $50 \%$ of materials costs and provided all the technical and logistic support for conducting this study with precise and correct methods and protocols of throughput real-time RT qPCR assay.

\section{Conflict of Interest}


The author declares that there is no any kind of conflict of interests regarding the publication of this paper.

\section{Funding}

This research was funded by Kent State University and Fulbright organization.

\section{References}

1. Naing ZW, Scott GM, Shand A, et al. Congenital cytomegalovirus infection in pregnancy: a review of prevalence, clinical features, diagnosis and prevention. Aust N Z J Obstet Gynaecol. 2016; 56(1): 9-18.

2. Richardson AK, Currie MJ, Robinson BA, et al. Cytomegalovirus and Epstein-Barr virus in breast cancer. PloS One. 2015; 10(2): e0118989. doi: 10.1371/journal.pone.0118989.

3. Navarro D. Expanding role of cytomegalovirus as a human pathogen. Journal of medical virology. 2016; 88(7): 1103-12.

4. Plachter B, Sinzger C, Jahn G. Cell types involved in replication and distribution of human cytomegalovirus. Adv Virus Res. 1996; 46: 195-261.

5. Jacobs JP, Jones CM, Baille JP. Characteristics of a human diploid cell designated MRC-5. Nature. 1970; 227(5254): 168-70.

6. Pandey JP. Immunoglobulin GM genes, cytomegalovirus immunoevasion, and the risk of glioma, neuroblastoma, and breast cancer. Front Oncol. 2014;4:236.

7. Geder L, Kreider J, Rapp F. Human cells transformed in vitro by human cytomegalovirus: tumorigenicity in athymic nude mice. J Natl Cancer Inst. 1977; 58(4): 1003-9.

8. Doniger J, Muralidhar S, Rosenthal LJ. Human cytomegalovirus and human herpes virus 6 genes that transform and transactivate. Clin Microbiol Rev. 1999; 12(3): 367-82.

9. Nelson JA, Fleckenstein B, Jahn G, et al. Structure of the transforming region of human cytomegalovirus AD169. J Virol. 1984; 49(1): 109-15.

10. Michaelis M, Doerr HW, Cinatl J. The story of human cytomegalovirus and cancer: increasing evidence and open questions. Neoplasia. 2009; 11(1): 1-9.

11. Soderberg-Naucler C. Does cytomegalovirus play a causative role in the development of various inflammatory diseases and cancer? J Int Med. 2006; 259(3): 219-46.

12. Harkins L, Volk AL, Samanta $M$, et al. Specific localization of human cytomegalovirus nucleic acids and proteins in human colorectal cancer. Lancet. 2002; 360(9345): 1557-63.

13. Mitchell DA, Xie W, Schmittling $R$, et al. Sensitive detection of human cytomegalovirus in tumors and peripheral blood of patients diagnosed with glioblastoma. Neuro-oncology. 2008; 10(1): 10-8.

14. Samanta M, Harkins L, Klemm K, et al. High prevalence of human cytomegalovirus in prostatic intraepithelial neoplasia and prostatic carcinoma. J Urol. 2003; 170(3): 998-1002.

15. Cinatl J, Jr., Vogel JU, Cinatl J, et al. Long-term productive human cytomegalovirus infection of a human neuroblastoma cell line. Intl J Cancer. 1996; 65(1): 90-6.

16. Hoever G, Vogel JU, Lukashenko P, et al. Impact of persistent cytomegalovirus infection on human neuroblastoma cell gene expression. Biochem Biophys Res Commun. 2005; 326(2): 395-401.

17. Grassi G, Maccaroni P, Meyer R, et al. Inhibitors of DNA methylation and histone deacetylation activate cytomegalovirus promoter-controlled reporter gene expression in human glioblastoma cell line U87. Carcinogenesis. 2003; 24(10): 1625-35.

18. McSharry BP, Jones CJ, Skinner JW, et al. Human telomerase reverse transcriptase-immortalized MRC5 and HCA2 human fibroblasts are fully permissive for human cytomegalovirus. J Gen Virol. 2001; 82(Pt 4): 855-63.

19. Jacobbergar JW. FD, Lehman JM. Analysis of intracellular antigens by flow cytometry. Cytometry. 1986; 7(11): 356-64.

20. Song D, Cui M, Zhao G, et al. Pathway-based analysis of breast cancer. Am J Transl Res. 2014; 6(3): 302-11.

21. GenCards. GeneCards ${ }^{\circledR}$ : The Human Gene Database. 2016.

22. Abdulamir AS, Hafidh RR, Bakar FA. Molecular detection, quantification, and isolation of Streptococcus gallolyticus bacteria colonizing colorectal tumors: inflammation-driven potential of carcinogenesis via IL-1, COX-2, and IL-8. Mol Cancer. 2010; 9: 249. doi: 10.1186/1476-4598-9-249.

23. Abdulamir AS, Hafidh RR, Abu Bakar F. The association of Streptococcus bovis/gallolyticus with colorectal tumors: the nature and the underlying mechanisms of its etiological role. J Exp Clin Cancer Res. 2011; 30: 11. doi: 10.1186/1756-9966-30-11.

24. Sethi G, Kwon Y, Burkhalter RJ, et al. PTN signaling: Components and mechanistic insights in human ovarian cancer. Mol Carcinog. 2015; 54(12): 1772-85.

25. Chen Y, Choong LY, Lin Q, et al. Differential expression of novel tyrosine kinase substrates during breast cancer development. Mol Cell Proteomics. 2007; 6(12): 2072-87.

26. Didierlaurent A, Brissoni B, Velin D, et al. Tollip regulates proinflammatory responses to interleukin-1 and lipopolysaccharide. Molecular and cellular biology. 2006; 26(3): 735-42.

27. Warr N, Siggers $P$, Carre GA, et al. Genetic analyses reveal functions for MAP2K3 and MAP2K6 in mouse testis determination. Biol Reprod. 2016 May;94(5):103. doi: 10.1095/biolreprod.115.138057. 
28. Xie X, Song J, Li G. MiR-21a-5p suppresses bisphenol A-induced pre-adipocyte differentiation by targeting map2k3 through MKK3/p38/MAPK. Bioch Biophys Res Commun. 2016; 473(1): 140-6.

29. Jia M, Souchelnytskyi N, Hellman U, et al. Proteome profiling of immortalization-to-senescence transition of human breast epithelial cells identified MAP2K3 as a senescence-promoting protein which is downregulated in human breast cancer. Proteomics Clin Appl. 2010; 4(10-11): 816-28.

30. Liu R, Li J, Lai Y, et al. Hsa-miR-1 suppresses breast cancer development by down-regulating $\mathrm{K}$-ras and long non-coding RNA MALAT1. Int J Biol Macromol. 2015; 81: 491-7.

31. Ge YZ, Wu R, Lu TZ, et al. Combined effects of TGFB1 +869 T/C and +915 G/C polymorphisms on acute rejection risk in solid organ transplant recipients: a systematic review and meta-analysis. PloS One. 2014; 9(4): e93938. doi: 10.1371/journal.pone.0093938.

32. Pal SK, Nguyen CT, Morita KI, et al. THBS1 is induced by TGFB1 in the cancer stroma and promotes invasion of oral squamous cell carcinoma. J Oral Pathol Med. 2016; 45(10): 730-39.

33. Vergne I, Gilleron M, Nigou J. Manipulation of the endocytic pathway and phagocyte functions by Mycobacterium tuberculosis lipoarabinomannan. Front Cell Infect Microbiol. 2014; 4: 187. doi: 10.3389/fcimb.2014.00187.

34. Yang SX, Polley E, Lipkowitz S. New insights on PI3K/AKT pathway alterations and clinical outcomes in breast cancer. Cancer Treat Rev. 2016; 45: 87-96.

35. Fresno Vara JA, Casado E, de Castro J, et al. PI3K/Akt signalling pathway and cancer. Cancer Treat Rev. 2004; 30(2): 193-204.

36. Falasca M. PI3K/Akt signalling pathway specific inhibitors: a novel strategy to sensitize cancer cells to anti-cancer drugs. Curr Pharmaceut Design. 2010; 16(12): 1410-6.

37. Paplomata E, O'Regan $R$. The PI3K/AKT/mTOR pathway in breast cancer: targets, trials and biomarkers. Ther Adv Med Oncol. 2014; 6(4): 154-66.

38. Roomi MW, Monterrey JC, Kalinovsky $\mathrm{T}$, et al. Patterns of MMP-2 and MMP-9 expression in human cancer cell lines. Oncol Rep. 2009;21(5): 1323-33.
39. Xie $T$, Dong $B$, Yan $Y$, et al. Association between MMP-2 expression and prostate cancer: A metaanalysis. Biomed Rep. 2016; 4(2): 241-5.

40. Biasiolo $A$, Tono $N$, Ruvoletto $M$, et al. IgM-linked SerpinB3 and SerpinB4 in sera of patients with chronic liver disease. PloS One. 2012; 7(7): e40658. doi: 10.1371/journal.pone.0040658.

41. Zhang Y. CKS1B (CDC28 protein kinase regulatory subunit 1B). Atlas of genetics and cytogenetics in oncology and haematology. Accessed 2016. http://atlasgeneticsoncology.org/Genes/CKS1BID400 92ch1q21.html.

42. Fujita $Y$, Yagishita S, Hagiwara $K$, et al. The clinical relevance of the miR-197/CKS1B/STAT3-mediated PD-L1 network in chemoresistant non-small-cell lung cancer. Mol Ther. 2015; 23(4): 717-27.

43. Kim BH, Kim SY, Nam KH. Assessing the diverse functions of BAK1 and its homologs in arabidopsis, beyond BR signaling and PTI responses. Mol Cells. 2013; 35(1): 7-16.

44. Chinnam M, Goodrich DW. RB1, development, and cancer. Curr Topics Develop Biol. 2011; 94: 129-69.

45. Bohm S, Bernstein KA. The role of post-translational modifications in fine-tuning BLM helicase function during DNA repair. DNA Repair. 2014; 22: 123-32.

46. Katayama $H$, Yamashita $T$, Sengoku K, et al. [BOMP (BLM, VCR, MMC, and CDDP) therapy for advanced cervical cancer]. Nihon Rinsho. 2004; 62(Suppl 10): 187-91.

47. Iwamoto KS, Barber CL. Radiation-induced posttranscriptional control of M6P/IGF2 $r$ expression in breast cancer cell lines. Mol carcinog. 2007; 46(7): 497-502.

48. Siveen KS, Sikka S, Surana R, et al. Targeting the STAT3 signaling pathway in cancer: role of synthetic and natural inhibitors. Bioch Biophys Acta. 2014; 1845(2): 136-54.

\footnotetext{
E-mail: ahmed.sahib@colmedalnahrain.edu.iq

Received $10^{\text {th }}$ Oct. 2016: Accepted $1^{\text {st }}$ Dec. 2016
} 